\title{
SNCA wt Allele
}

National Cancer Institute

\section{Source}

National Cancer Institute. SNCA wt Allele. NCI Thesaurus. Code C90113.

Human SNCA wild-type allele is located in the vicinity of $4 \mathrm{q} 21$ and is approximately $111 \mathrm{~kb}$ in length. This allele, which encodes alpha-synuclein protein, is involved in presynaptic signaling and membrane trafficking. Mutation of the gene is associated with Alzheimer disease, Parkinson disease and Lewy body dementia. 